TECHNICAL INFORMATION SERISSP. O. BOX 11508

inte proge

GEPP -97001148 PROPERTY OF U. S. GOYERNMENT

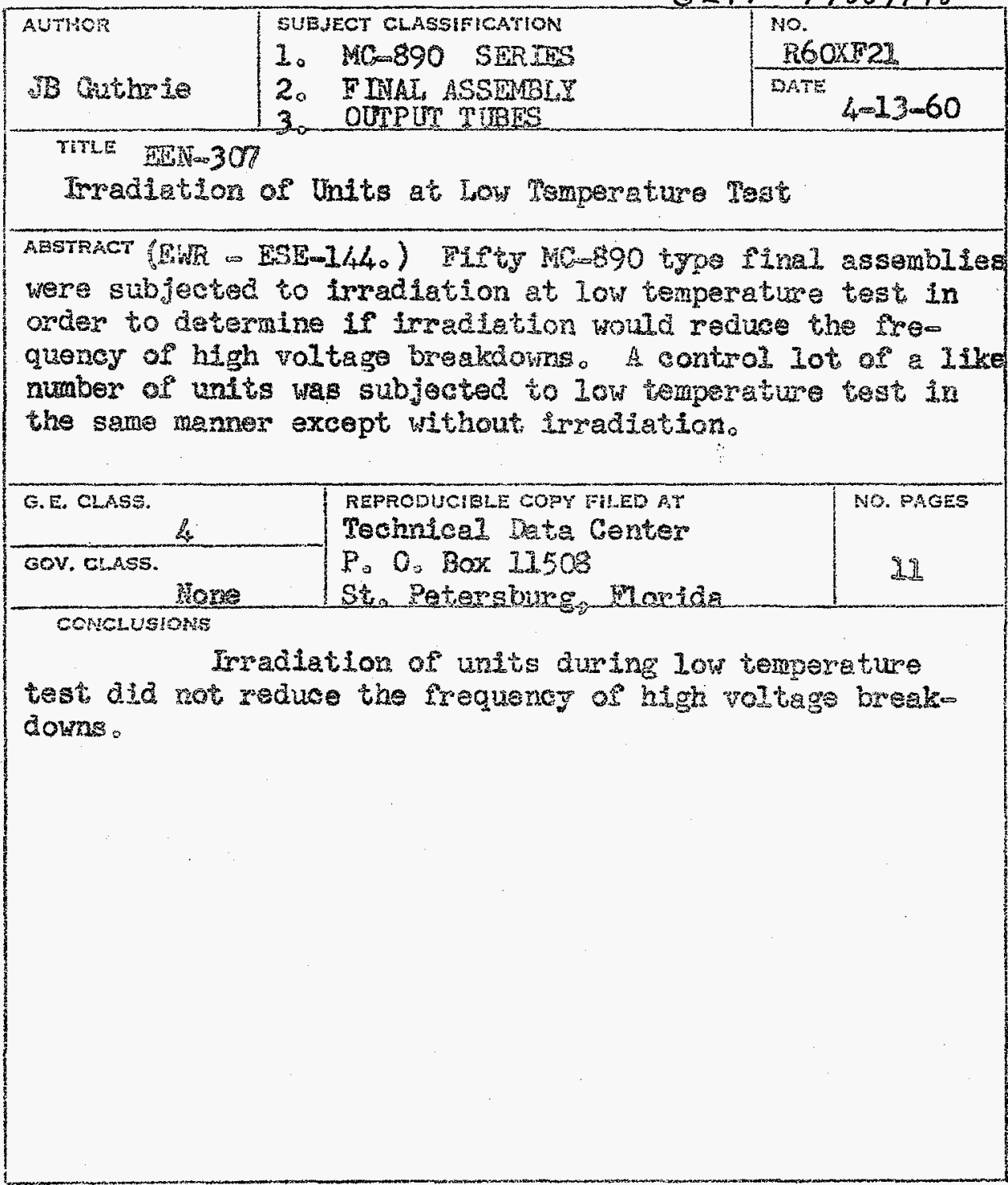

By cuting out this rectanglo and folding on the centur line the shove information cen be fitted into a standard card stlis.

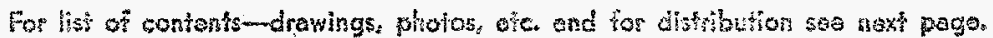

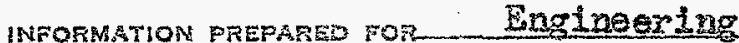

TESTS MADE gY- Quality control.

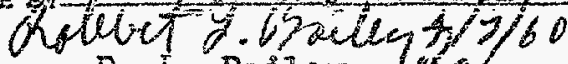

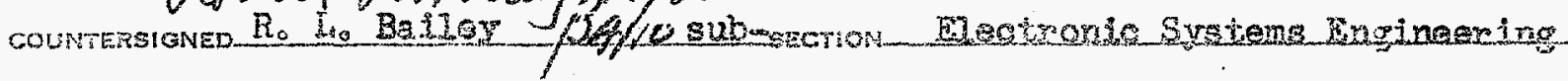

Division Industrial Elostrónics

St. Patarsbure. Morlda 
NO, PAGES TEXT

NO. CHARTS

DRAWING NOS.

PHOTO NOS.
0

APPENDIX

\section{Text Gharts}

5
2
DISTRIBUTION

\section{GEX}

RL Ba110y

AF Bischoff

CC Browt

DF Brown

VT Burkets

RR Ceba 11

JS Cavar

CD French

CE Jay

AD MeCorern

RA Patriok

AF Poso 28

GP Petorsen

LM Sherwood

HR Sino

WJ Stapletoo

D Weinberger

WJ Wood

Technica 1 Lata Contox (5)

\section{GEX}

RH Bogton

HR Cumings

WE Johnston

MU Osbora

Ric Stroble

Gy Feed

Pr. WLISOS

$\mathrm{ABC}$

JH Sund

\section{SAMDIA}

BH Bus $190,2411 \times B$

Wf Carstens. 4723

TS Chwer, 240

JJ Dawson, 1414

II DePen 145

Wh Pros, 2542

TP Shoupg 1413

TJ Ihes lis, 2542

7 WLesen, 1592

ISS Poldard, 1411-3 


\section{TABLE CONTEHTS}

\section{Page}

Io INTRODJCTION

II. TEST CONDITION

III. TRST RESULTS

IV. CONCLLSIONS

APPENDIX

$6-10$

CHART

21 
So IMIRODUCT ION

GEXM report No. GEX-251 (GEM-460) shows in a quentitative manner the butldup of electrical cherge on the walls of the output tubs as a number of successive operations is increased. It was also reported that the charge can be dissipated by iro radiation of the tube with X-rays of $50 \mathrm{KVP}, 2$ mllilamp seconds at a distance of 1 foot in air. The tims constant of charg dissipation without irradintion was found to be approximately 7 minutes at room temperature。

Ifigh voltage brealedowns of final assemblles tested at low temperature also appear to be a time related effect. Data from quality Control shows that the high voltage breakdown rate is approxinately $0.2 \%$ on the first operation and increases to a rate of over $1 \%$ on the fifth operation, operating at a 3 minute interval between operations. The frequency of high voltege breakdowns is inversely proportionel to the interval between operatlons. It was surmised that high valtage breakdown at low temperature was due in part to the accumulation of charges on the walls of the tube. It was expedted that $\mathrm{X}$-radiation between operations would elininate this charge and in turn redue the froquency of high voltage breakdows on the second, thisd, fourth, and fifth operation. In order to test this hypothesis, arrangements were made to subject 50 MC 1140 (M-890 typo) units to X-radiation between aporations at Low tem perature test. The lot was divided into 2 gqual parts for control purposes。

II. TEST CONDIFION

The 50 untts selected for this test wer MC-1140 type which previousiy bed failed to qualify as MC-890 du to one high voltage breakdown at low temperature. MC-1140 units were used in preference to MC 890 type untts because the latter vere not avallable at the time. The 50 units were randomly divided into 2 groups of 25 each and labeled gro up A and group B respeotivelyo Both groups were placed in temperature chambers and the temporature wes reducad to $-65^{\circ}$ for 8 hours minirum. Alo ternate units from groups A and B were removed from the chamber one at a time and subjected to 5 oparations at 1 minuto intervals, 24 volts input, 650 volts trigger and 4 second warm-up. Inits from group $A$ tere subjected to $X-a d i a t i o n$ after ach operation of the unit and units from group $B$ were tested in an ldenticel manner axcept they were not irradiatod. The X-ray equipaent used sas Ceneral Flectric type 0X250 set at $250 \mathrm{KV}, 10 \mathrm{mLllianps}$ for an exposure the of appsoximately 13 second 0 The X-ray target was set at a distance of 14 inehes from the center of the product output tube to be irrediated. At the completion of $t$ his tost, lots $A$ ard $B$ wero reversed and the tests were zeperad oxcept the otbar group was irradiatod. This resultod in 250 opsrations on each group of 25 urits, of which 125 operations wase interposed by irradiation.

\section{TEST RESULS}

Dotalls of high voltage breakdows according to urit serlal numbers are shown on the attached Quality Control Engineor Ing Analys is and the results may bo summarized as follow: 
Irradiated 250 operations Non irradieted 250 operations
9 High Voltage Breakdowns。

11 Hilgh voltage breakdowns.

Tost for significanoe by the Quality Control Engineor showed no signific cant difference between the irradiated and non-1rradiated groups.

IV。

\section{GOMCEUSIONS}

Based on the results of the above experiment lawolving a quantity of 50 units, 1rradiation between operations at cold test does not result in reduction of high voltage breakdowns on the second, third, fourth, and fifth operations. 
QUATIIY CONTROL ENGINEERING ANALYSIS

MARCH 19.960

EEN 307 SPECIAL LON IEMPERATURE TEST

\begin{tabular}{|c|c|}
\hline DISTRIBUT ION & 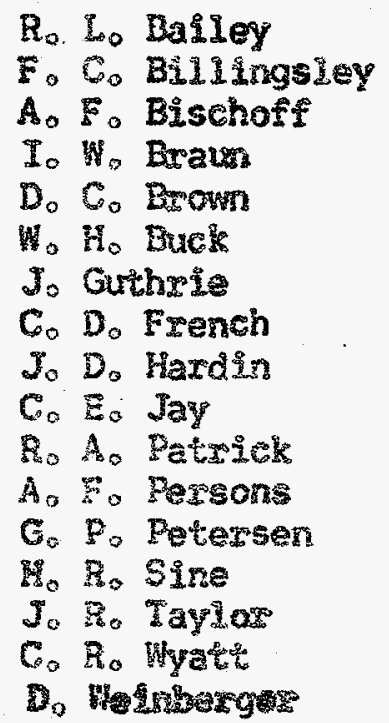 \\
\hline
\end{tabular}

$-6=$ 
QUALITY CONTROL ENGINEERING ANALYS IS

MARCH 12.1960

EEN 307 - SPECIAL LOU TEMPERATURE TEST

PURPOSE: To imvestigate the theory that wery radiation will reduce the incidence of high voltage breakio down.

SUMARY Results indicate that there Is no significant difference betueen units soray madiated and those not seray radiated when subjected to radiation in the manner outlined in EEN-307. 


\section{QUALIY CONTROL ENGINEERING ANALSS IS}

\section{March 1 I. 1960}

\section{EEN $=307=$ SPECIAL LOA TEMPERATURE TEST}

PURPOSE: To Investigate the theory that $x$ say radiation will reduce the Incidence of high yoltage bxeakdowns.

METHCD: 50 units tore zandonly divided Into groups of 25 as follows:

\begin{tabular}{|c|c|c|c|c|}
\hline \multicolumn{2}{|c|}{${ }^{8} A^{\text {晤 }}$} & & \multicolumn{2}{|c|}{$53^{\infty}$} \\
\hline 409022 & 535030 & & 407015 & 535047 \\
\hline 506020 & 545244 & & 505006 & 535088 \\
\hline 506027 & 545145 & & 506077 & $\$ 35186$ \\
\hline 506028 & $\$ 4583$ & & 506124 & 535197 \\
\hline 506048 & 555030 & & 506199 & 545036 \\
\hline 506073 & 555031 & - & $50613^{\circ}$ & 545044 \\
\hline 506134 & 555080 & & 50652 & 545054 \\
\hline 506181 & 555083 & & 506156 & 54513 \\
\hline 506192 & 555146 & & 506263 & 545166 \\
\hline 511053 & 555176 & & 511021 & 545174 \\
\hline 511064 & 555178 & & 5105 & 355347 \\
\hline 58.096 & $555] 89$ & & 5.1059 & 553186 \\
\hline 511098 & & & 511065 & \\
\hline
\end{tabular}

Both groups were put into Consad chanbers and the temperature was gem

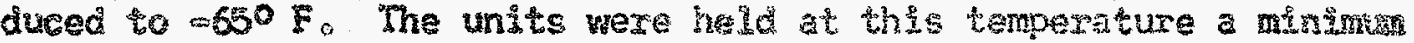
of eight hours. Alternate units were renoved ron the chambers one at a time and subjected to $F$ ive operatzons at one mate interals.

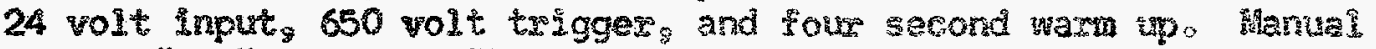

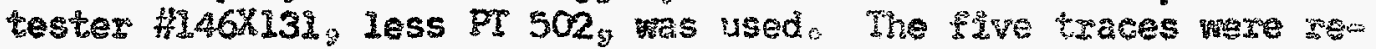

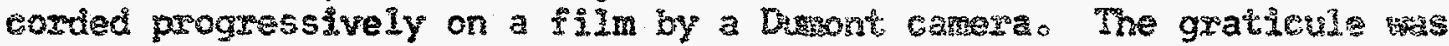

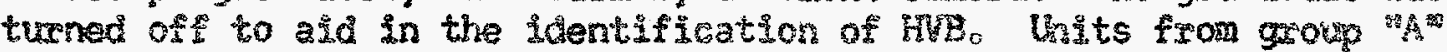
were subjected to zoray wadiation arter each oparation of the unst.

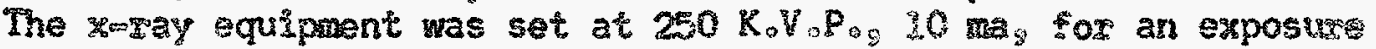
the of approximately 13 seconds. The distance of $14^{\text {th }}$ from taxget to centex of product tube was used after preliningry axporiment ind

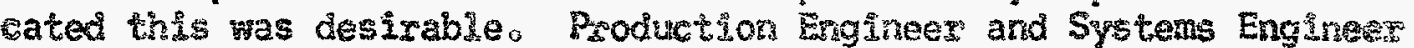
were in agreement with this. Grove "Bo was rot xadiated.

At the completion of the above seguenge of 50 trests the lots were reversed and the experiment performed as above extept group "9.

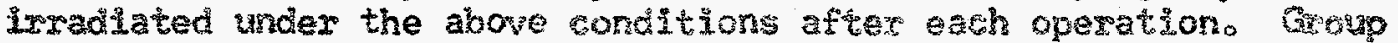

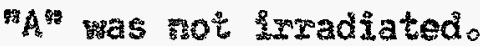

RESULTS: Refer to Chart H.

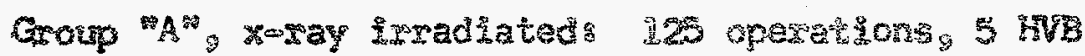

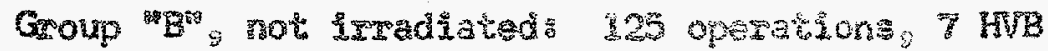

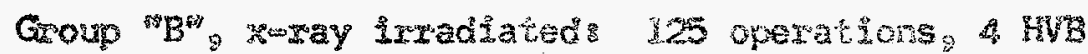

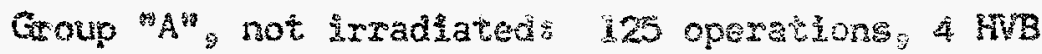




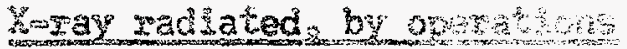

\begin{tabular}{|c|c|}
\hline Grouro ${ }^{~} A^{\text {* }}$ & roono $\mathrm{B}$ \\
\hline 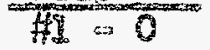 & $\mathrm{HI}=\mathrm{O}$ \\
\hline $42-0$ & $A y_{z}=\mathrm{B}$ \\
\hline$\$ 3=1$ & $M=0$ \\
\hline$\$ 4=3$ & $H a$ \\
\hline$+5=1$ & $4=3$ \\
\hline
\end{tabular}

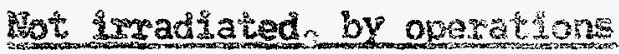

\begin{tabular}{|c|c|}
\hline Grour " ${ }^{\prime \prime}$ & Mon \\
\hline $41=0$ & $F=\frac{1}{2}$ \\
\hline $12=0$ & $42=9$ \\
\hline $43=1$ & 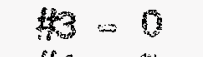 \\
\hline $44-1$ & $f(4)=5$ \\
\hline$t w=2$ & $4=0$ \\
\hline
\end{tabular}

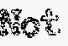

\begin{tabular}{|c|c|c|c|c|c|}
\hline A & Ir adiated & Trediatad & 8 & Imadiared & Ispadiater \\
\hline 409022 & $0 / 5$ & $0 / 5$ & 407015 & $0 / 5$ & $0 / 5$ \\
\hline 506020 & $0 / 5$ & $0 / 5$ & 506006 & $0 / 5$ & $0 / 5$ \\
\hline 506027 & $0 / 5$ & $0 / 5$ & 506077 & $0 / 5$ & $0 / 5$ \\
\hline 506028 & $0 / 5$ & $0 / 5$ & 506124 & $0 / 5$ & $0 / 5$ \\
\hline 506040 & $2 / 5, \quad 43,44$ & 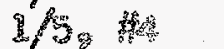 & 50619 & $0 / 5$ & $0 / 5$ \\
\hline 506073 & $0 / 5$ & $0 / 5$ & 506937 & $0 / 5$ & $0 / 5$ \\
\hline 506234 & $1 / 5$ & $y / 5$, & 506952 & $0 / 5$ & $0 / 5$ \\
\hline 506288 & $0 / 5$ & $0 / 5$ & 506256 & $4 / 5,45$ & $D / 5,43$ \\
\hline 506192 & $0 / 5$ & $0 / 5$ & 506163 & $0 / 5$ & $0 / 5$ \\
\hline 518053 & $1 / 5,8$ & $\delta / 5$ & 511021 & $0 / 5$ & $0 / 5$ \\
\hline 511064 & $0 / 5$ & $0 / 5$ & 511058 & $0 / 5$ & $0 / 5$ \\
\hline 514096 & $0 / 5$ & $1 / 5,3$ & 51.059 & $0 / 5$ & $0 / 5$ \\
\hline 519098 & o/s & $0 / 5$ & 51905 & $0 / 5$ & $1 / 5,4$ \\
\hline 535030 & $0 / 5$ & $0 / 5$ & 535047 & $0 / 5$ & $0 / 5$ \\
\hline 54504 & $0 / 5$ & $0 / 5$ & 535088 & $0 / 5$ & $0 / 5$ \\
\hline $545: 45$ & $0 / 5$ & $0 / 5$ & 535986 & $0 / 5$ & $0 / 5$ \\
\hline 545183 & $0 / 5$ & $0 / 5$ & 53597 & $1 / 5,45$ & $0 / 5$ \\
\hline 555030 & $0 / 5$ & $0 / 5$ & 545036 & $0 / 5$ & $0 / 5$ \\
\hline 555031 & $0 / 5$ & $0 / 5$ & 545044 & $0 / 5$ & $8 / 55,42$ \\
\hline 555080 & $0 / 5$ & $0 / 5$ & 54505 & $0 / 5$ & $0 / 5$ \\
\hline 555083 & $0 / 5$ & $0 / 5$ & 5451,32 & $0 / 5$ & $0 / 5$ \\
\hline 555.46 & $/ 5$ & $0 / 5$ & 545166 & is $/ 5,4$ & $9 / 59$ \\
\hline 555176 & $0 / 5$ & $0 / 5$ & 545174 & $0 / 5$ & $0 / 5$ \\
\hline 555178 & $0 / 5$ & $0 / 5$ & $555 \%$ & $2 / 5,44$ & $1 / 59$ 梦 \\
\hline 555189 & $0 / 5$ & $1 / 5,43$ & 555286 & $0 / 5$ & $2 / 5$, Hoth \\
\hline
\end{tabular}

These werg no ind Ications of abnomal operations. 
CONELUSONS

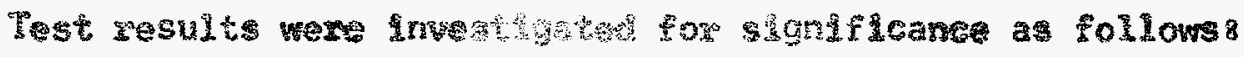

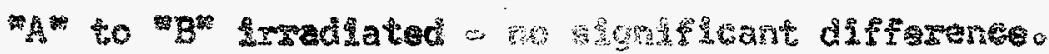

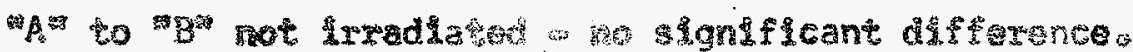

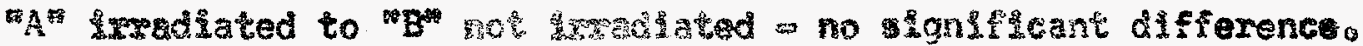

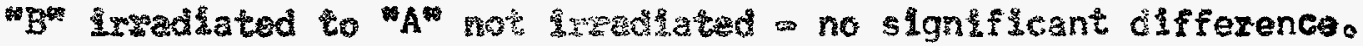

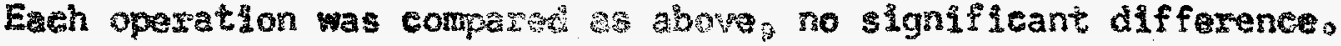

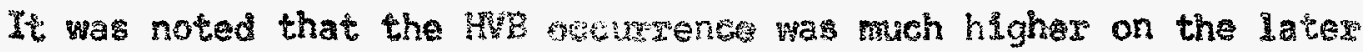

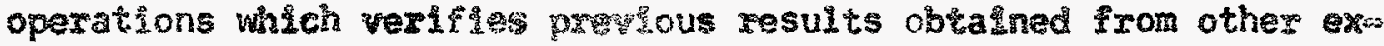
perinenta selating interapes and HV wate.

Theresores the conclusion is that xwoy radiation performed as per this axperiment makes no significant difference in the HVI3 wate.

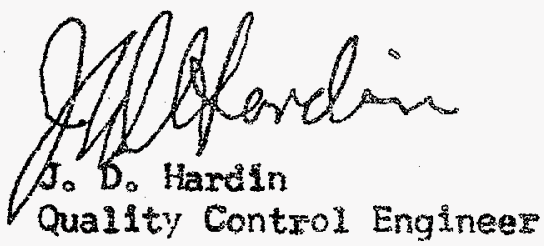

JDHisw 


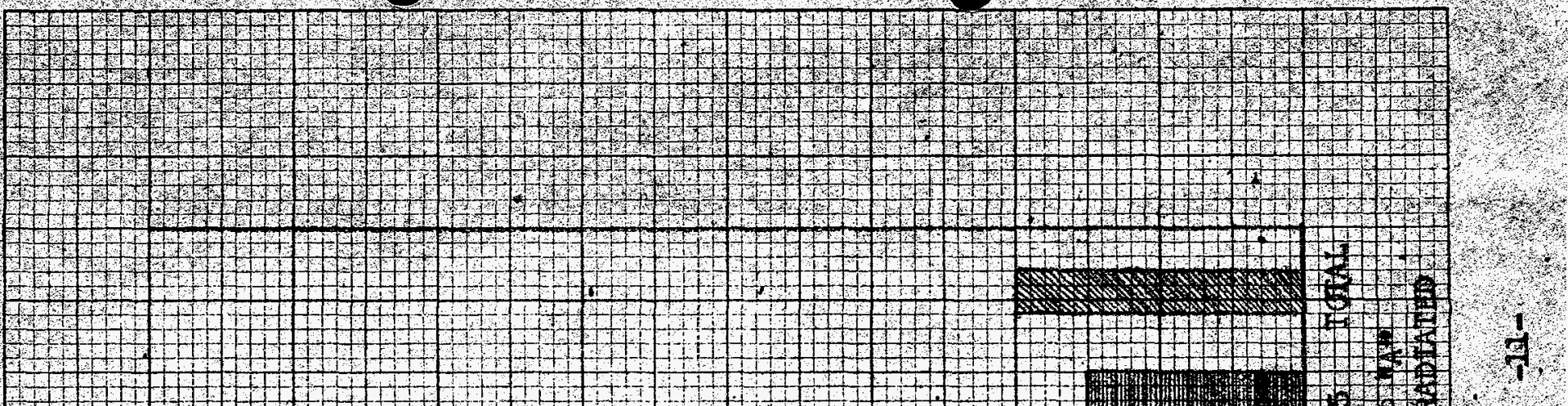

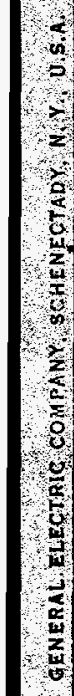

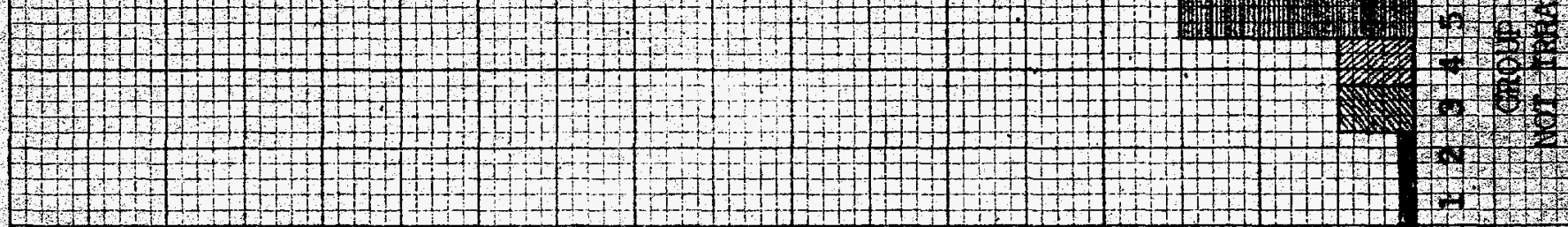
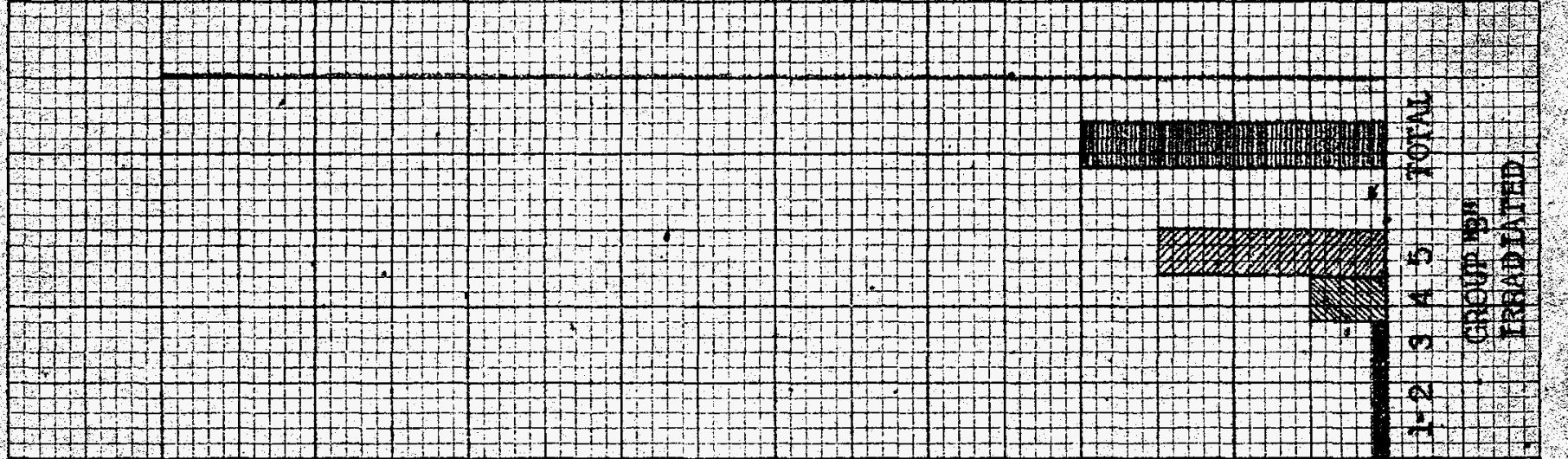

4
$\frac{5}{5}$
$\frac{5}{6}$
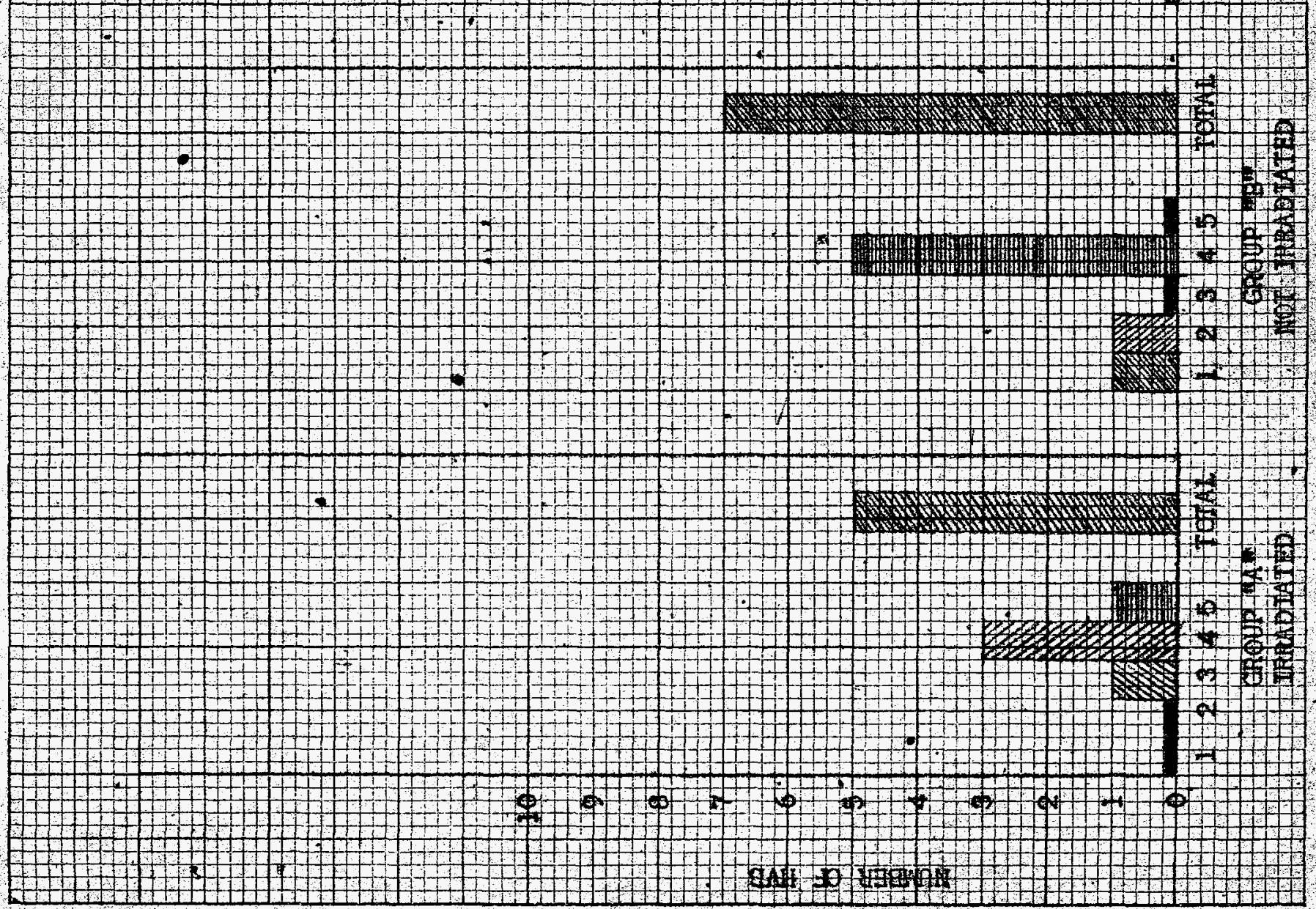


\section{DISCLAMMER}

Portions of this document may be illegible in electronic image products. Images are produced from the best available original document. 


\section{DISCLAIMER}

This report was prepared as an account of work sponsored by an agency of the United States Government. Neither the United States Government nor any agency thereof, nor any of their employees, makes any warranty, express or implied, or assumes any legal liability or responsibility for the accuracy; completeness, or usefulness of any information, apparatus, product, or process disclosed, or represents that its use would not infringe privately owned rights. Reference herein to any specific commercial product, process, or service by trade name, trademark, manufacturer, or otherwise does not necessarily constitute or imply its endorsement, recommendation, or favoring by the United States Government or any agency thereof. The views and opinions of authors expressed herein do not necessarily state or reflect those of the United States Government or any agency thereof. 